\title{
Pindorama contra Brazil
}

\author{
José D’Assunção Barros'
}

Pindorama estava em guerra

Contra um país chamado Brazil

E uma gente vestida em verde

Veio convocar a juventude

Para lutar do lado errado

Aos que não foram, deram um paredão

Uma venda e um pelotão do outro lado

E uma coisa abstrata chamada morte

Mas que talvez não passasse de uma passagem

Para o Campo de Caça Feliz

Aos que foram, deram um fuzil

Prometeram uma medalha e disseram

- Vai, e me traz um índio!

Aquela guerra estava fadada a não terminar nunca

Porque também era a guerra contra os passarinhos

Contra as borboletas, e o que sobrou de ar puro

Para vencê-la, seria preciso matá-los todos

Ou convertê-los à cor cinza

1 Professor-Associado da Universidade Federal Rural do Rio de Janeiro, nos cursos de Graduação e Pós-Graduação em História, Professor-Permanente do Programa de Pós-Graduação em História Comparada da Universidade Federal do Rio de Janeiro. Doutor em História pela Universidade Federal Fluminense. ORCID id: 0000-0002-3974-0263 E-mail: jose.d.assun@globomail.com 
Quanto a mim - este índio civilizado -

Ficarei para sempre no espaço

Intermediário que chamam de limbo

... A floresta, ali não entrarei

A cidade... jamais entrará em mim... 